\title{
Efficacy of the decoction of cashew leaf (Spondias mombin L.) as a natural antiseptic in dairy goat matrices
}

\author{
Camila Fernandes Leonêz ${ }^{1}$, Francisco Marlon Carneiro Feijó ${ }^{2}$, Nilza Dutra Alves ${ }^{2}$, Caio Sergio \\ Santos $^{2}$, Gardênia Silvana Oliveira Rodrigues ${ }^{2 *}$, Fernando da Costa Fernandes ${ }^{1}$ and \\ Tayná Moura Matos ${ }^{1}$ \\ ${ }^{1}$ Department of Veterinary Medicine, Federal Rural University Semi-arid, City of Mossoró, State of Rio \\ Grande do Norte, Brazil. \\ ${ }^{2}$ Department of Plant Sciences, Federal Rural University Semi-arid, City of Mossoró, State of Rio \\ Grande do Norte, Brazil.
}

Received 25 September, 2017; Accepted 20 October, 2017

\begin{abstract}
Microorganisms resistant to conventional antimicrobial substances are becoming more prevalent. Accordingly, natural alternatives have been sought with the use of extracts from medicinal plants whose purpose is to find new compounds with recognized antimicrobial activity. This work aims to show the efficacy of the cajá (Spondias mombin L.) leaf decoction using the microplate dilution technique against Staphylococcus sp, a bacterial strain isolated from cases of subclinical mastitis in dairy goat matrices. The $5 \%$ probability test was used to compare the means among the studied treatments. Leaf extract from the cajá was effective at concentrations of 1:1 and 1:2 against all strains of Staphylococcus coagulase negative, regardless of storage temperatures. All strains were resistant to amoxicillin + clavulanate, ampicillin, cefepime and ceftazidime, being characterized with a multiresistant profile.
\end{abstract}

Key words: Staphylococcus sp. microorganisms, decoction, Spondias mombin L.

\section{INTRODUCTION}

Inflammatory and non-infectious diseases are traditionally treated with anti-inflammatories, which are usually expensive. Consequently, it is indispensable to find alternative products for microbial control that are economical and ecologically viable. With the need for new alternatives to combat disease, studies have been conducted using plants from the northeastern semiarid as a therapeutic option for this problem. The field man's empirical knowledge regarding medicinal plants and their therapeutic power over some diseases was combined

${ }^{*}$ Corresponding author. E-mail: gardeniavg@yahoo.com.br.

Author(s) agree that this article remain permanently open access under the terms of the Creative Commons Attribution License 4.0 International License 
with the tests that proved the phyto-therapeutic effectiveness of some of these plants.

The use of medicinal plants as an alternative therapy, with an emphasis on microbial inhibition by natural antiseptic agents, has become a beneficial action for the sertanejo that survives from the caatinga, since conventional alternatives are often inappropriate to socioenvironmental conditions. Among these alternative plants is Spondias mombin L, which is also known as cajazeira, cajazeira-miúda, taperebá or cajá-mirim.

The cajazeira is a leafy tree with a wide and imposing crown during the phase of flowering and fruiting. As for the taxonomic classification, S. mombin L. is of the family Anacardiaceae; Tribe- Spondiadeae; Genus- Spondias L. (Barroso et al., 1999). On the chemical constitution of cajazeira, Diby et al. (2012) identified the presence of alkaloids, flavonoids, polyphenols, quinones, saponins, gallic tannins and terpenes in the stem bark. Regarding its ethnopharmacological characteristics, it has been reported that all parts of the plant have medicinal properties.

The aromatic bark, both astringent and emetic, constitutes a good vomitory in the cases of bilious fevers and palustres, and has an antidiarrheal, antidisintegrating, antiblenorrhagic and anti-hemorrhoidal reputation (the last property also attributed to the root). The leaves are useful against bilious fever, constipation of the stomach, pains of the stomach etc. In recent years, it has been found that extracts from the leaves and branches of the cajazeira contain gallic tannins with medicinal properties for the control of gram negative and positive bacteria (Sacramento and Souza, 2000). Medeiros (2013) observed flavonoids, catechins, flavanones, xanthones and free steroids in the leaf of the cajá in addition to the presence of tannins.

Therefore, the aim of the present study was to analyze the efficacy of antiseptic on the base of the leaflet ( $S$. mombin) against strains of bacterial Staphylococcus sp. across different storage times and temperatures.

\section{MATERIALS AND METHODS}

\section{Preparation of the decoction of the leaf of cajá}

The leaves of S. mombin L. were harvested at 07:00 am in April 2017 from a specimen on the campus of the Federal Rural SemiArid Federal University (Universidade Federal Rural do SemiÁrido). The samples were packaged in black bags and taken to the UFERSA Veterinary Microbiology Laboratory for decoction processing. Previously, the exsicata was taken to Herbarium Dárdaro de Andrade Lima to be cataloged, where it received the following numbering: $S$. mombin L. - 13953. About $100 \mathrm{~g}$ of $S$. mombin leaves were collected and placed in a container with 200 $\mathrm{ml}$ of distilled water. This was boiled in a water bath for $15 \mathrm{~min}$ for the production of $200 \mathrm{ml}$ of decoction. The material was filtered on filter paper ${ }^{1}$ and stored in a sterile, amber glass bottle.

\footnotetext{
${ }^{1}$ It has an open texture, used in filtrations with fast speed of thick precipitates, with weight: $85 \mathrm{~g} / \mathrm{m}^{2}$ and Porosity: 7.50 microns (Brand: CAAL - CASA AMERICANASão Paulo)
}

\section{Decoction dish analysis}

The decoction was diluted with a serial dilution of $10^{-1}, 10^{-2}$ and $10^{-3}$ in distilled water tubes with $9 \mathrm{ml}$ each. Subsequent deposition of these dilutions in Petri dishes with Mueller-Hinton agar medium was analyzed in duplicate. These plates were kept in an oven at $37^{\circ} \mathrm{C}$ for $24 \mathrm{~h}$ to observe possible growth of CFU (colony forming units). This study was conducted in the same manner at 0 and $24 \mathrm{~h}$ for 0 and 7 days of the refrigerated decoct, and on the 7th day of the decoction, it was preserved at room temperature $\left(25^{\circ} \mathrm{C}\right)$. Ten strains of coagulase-negative Staphylococcus (LMV01, LMV02, LMV03, LMV04, LMV05, LMV06, LMV07, LMV08, LMV09 and LMV10) were isolated from milk collected from caprine matrices with subclinical mastitis.

\section{Preparation of the inoculum for in vitro test}

The standard inoculum of each microorganism cultured for MuellerHinton agar diffusion assay was obtained by sowing $\mathrm{BHI}$ broth in the log phase (exponential growth) at the concentration of 0.5 on the MacFarland scale for 18 to $24 \mathrm{~h}$. A sterile cotton swab was introduced into the suspension with the inoculum, which was rotated five times clockwise, squeezing it firmly against the inner wall of the tube above the liquid level so as to remove any excess inoculum in the swab. In the Mueller-Hinton agar dish, the microorganisms were distributed by pressing the swab over the entire sterile surface of the agar to ensure uniform distribution of the inoculum. Each bacterial strain was deposited on two dishes with the agar.

Determination of antimicrobial susceptibility through disc diffusion (Kirby-Bauer)

After inoculum distribution in the Petri dishes with the culture medium, 18 disks of the following antimicrobials were deposited: ampicillin $(10 \mu \mathrm{g})$, amoxicillin + clavulanic acid $(30 \mu \mathrm{g})$, aztreonam $(30 \mu \mathrm{g})$, cephalothin $(30 \mu \mathrm{g})$, cefepime $(30 \mu \mathrm{g})$, ceftriaxone $(30 \mu \mathrm{g})$, cefoxitin $(30 \mu \mathrm{g})$, ceftazidime $(30 \mu \mathrm{g})$, ciprofloxacin $(05 \mu \mathrm{g})$, chlorphenicol $(30 \mu \mathrm{g})$, streptomycin $(10 \mu \mathrm{g})$, gentamicin $(10 \mu \mathrm{g})$, novobiocin $(30 \mu \mathrm{g})$, piperacillin + tazobactam $(110 \mu \mathrm{g})$, polymyxin $(300 \mu \mathrm{g})$, sulfamethoxazole + trimethoprim $(25 \mu \mathrm{g})$, vancomycin $(30$ $\mu \mathrm{g})$ and tetracycline $(30 \mu \mathrm{g})$. After this procedure, the dishes were placed into a bacteriological oven at $37^{\circ} \mathrm{C}$ for $24 \mathrm{~h}$, after which the halos were read through a millimeter ruler.

\section{Preparation of the microdilution test}

The standard inoculum of each microorganism cultured for microdilution plate test was obtained by a second sowing of bacteria in $\mathrm{BHI}$ broth in log phase (exponential growth) at the concentration of 0.5 of the MacFarland scale for 18 to $24 \mathrm{~h}$. The study was performed in two 96-well microdilution plates (ALAMARß, Diadema, São Paulo, Brazil) arranged in 12 columns (1 to 12) and eight lines ( $A$ to $H$ ). Each microorganism and positive control with chloramphenicol was tested in duplicate. Next, $100 \mu \mathrm{l}$ of brain and heart infusion broth $(\mathrm{BHI})$ was inserted into each well. Then, $100 \mu \mathrm{l}$ of the cassava decoction (S. mombin) was inserted into the wells relative to the $1: 1$ concentrations and serial dilution of these wells was then made to the concentrations (1:2, 1:4 and 1:8). In the last well equivalent to that bacterium, $100 \mu \mathrm{l}$ was discarded so that the wells remained with equal amounts. This was followed by the inoculation of $5 \mu \mathrm{l}$ of suspension of the $\mathrm{BHI}$ microorganisms in each well. In the positive control, $100 \mu \mathrm{l}$ of previously diluted Chloramphenicol $(1 \mathrm{mg} / \mathrm{ml})$ in distilled water was deposited. Chloramphenicol was chosen because it was the best antimicrobial 


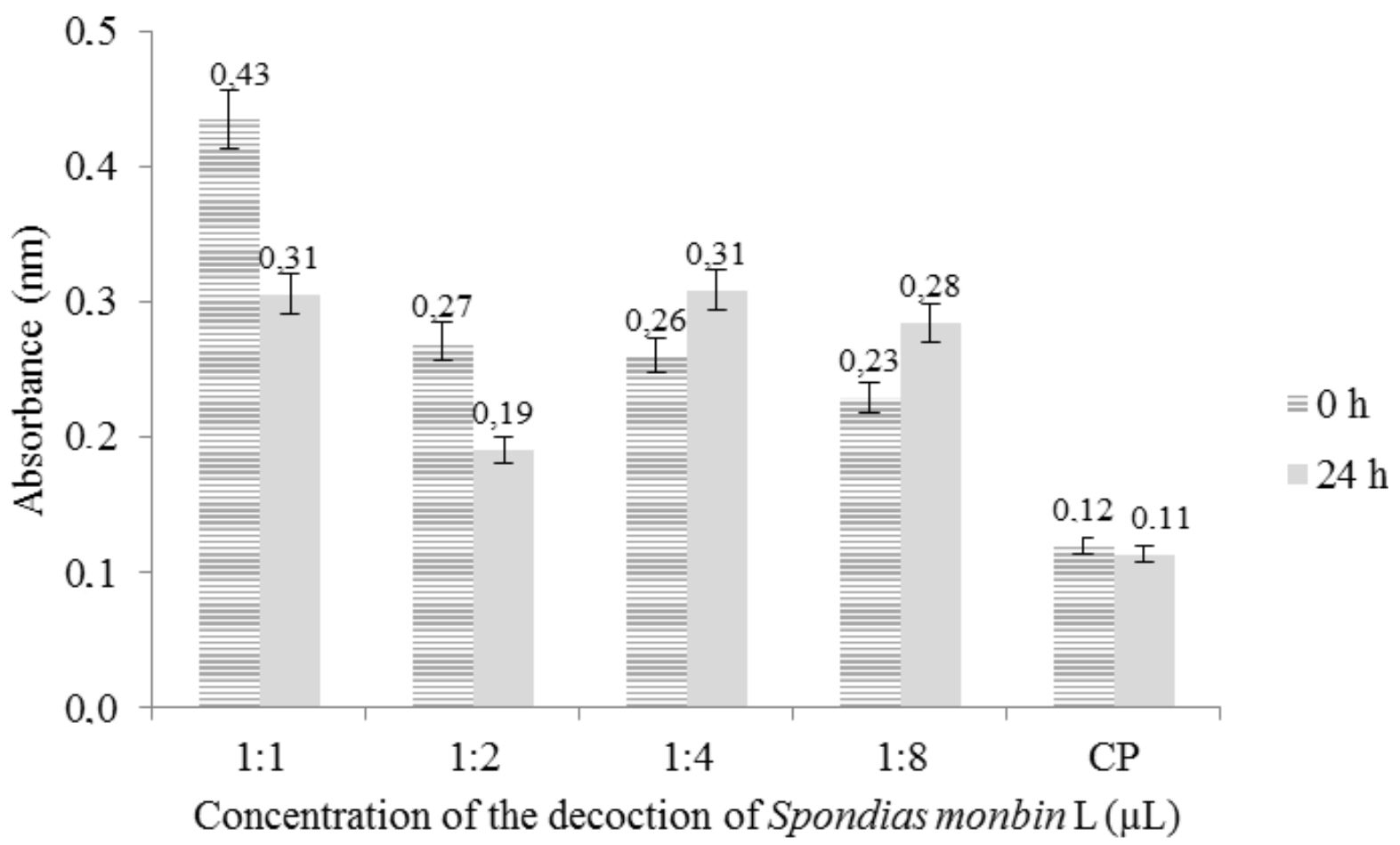

Figure 1. Absorbances according to the concentrations of the extracts of $S$. mombin and the time of culture of the bacteria with 0 and $24 \mathrm{~h}$, using decoct produced on day 0 .

in the disc-diffusion test, showing $100 \%$ effectiveness against strains of coagulase-negative Staphylococcus. After the preparation, the plates passed through the absorbance reader (URIT 660 - MICROPLATE READER). The well readings were performed at 0 and at $24 \mathrm{~h}$ on days 0 and 7 of refrigerated decoction, and on the 7th day of the decoction stored at room temperature $\left(25^{\circ} \mathrm{C}\right)$.

\section{Statistical analysis}

Considering the significance level of $5 \%$, Tukey's test was used to compare the means between treatments and performed with the software application SISVAR 3.01 (Ferreira, 2000)

\section{RESULTS AND DISCUSSION}

Plaque analysis for 0 and 7 days decoctions under refrigeration and maintained for 7 days at $25^{\circ} \mathrm{C}$ showed no bacterial growth. It was observed that the decoction kept for 7 days under refrigeration had concentrations of $1: 1$ and $1: 2$ and showed efficacy against the strains in relation to the other concentration results obtained on day 0 where it was analyzed at 0 and $24 \mathrm{~h}$. A decrease in absorbance was observed with differences of 0.12 and 0.08 , respectively, in relation to the hours at concentrations of $1: 1$ and $1: 2$.

This reduction relates to a smaller quantity of bacteria; thus, indicates the effectiveness of the concentration of decoction used. At concentrations of $1: 4$ and $1: 8$, the absorbance level increased $(0.05 \mathrm{~nm})$, thus showing bacterial growth in the wells using these concentrations (Figure 1).

Concerning the tests performed with the refrigerated decoction for 7 days, it is possible to verify a remarkable inhibition of the strains in concentrations of $1: 1$ and $1: 2$ of the extract, which varies from 0.20 to $0.42 \mathrm{~nm}$ and 0.15 to $0.31 \mathrm{~nm}$, at the initial time and $24 \mathrm{~h}$ later, respectively (Figure 2). A third analysis was performed with the cajá extract used after the 7th day at room temperature and at the concentration of $1: 1$, there was a decrease in absorbance of $0.10 \mathrm{~nm}$ in relation to $0 \mathrm{~h}(0.26 \mathrm{~nm})$ and 24 $\mathrm{h}(0.16 \mathrm{~nm})$ showing that there was significant inhibition by the decoction in relation to the strains tested. At $1: 2$ concentrations, the mean difference between the hours was much lower, but still inhibition was characterized by a decrease in the absorbance of $24 \mathrm{~h}(0.22 \mathrm{~nm})$ in relation to $0 \mathrm{~h}(0.24 \mathrm{~nm})$. The absorbance difference between these two hours was $0.02 \mathrm{~nm}$ (Figure 3).

There is no consensus regarding the level of inhibition acceptable for natural products when compared with standard antimicrobials; so much so that some authors consider only antimicrobial-like results, whereas others consider with good potential even those with higher levels of inhibition (Duarte, 2006). Matias (2012) study of the antibacterial activity of $S$. mombin extract and the inhibitory action of extracts at 1:1, 1:2, 1:4 and 1:8 concentrations mainly on coagulase-negative Staphylococcus, Staphylococcus aureus and Streptococcus sp found that only two concentrations 


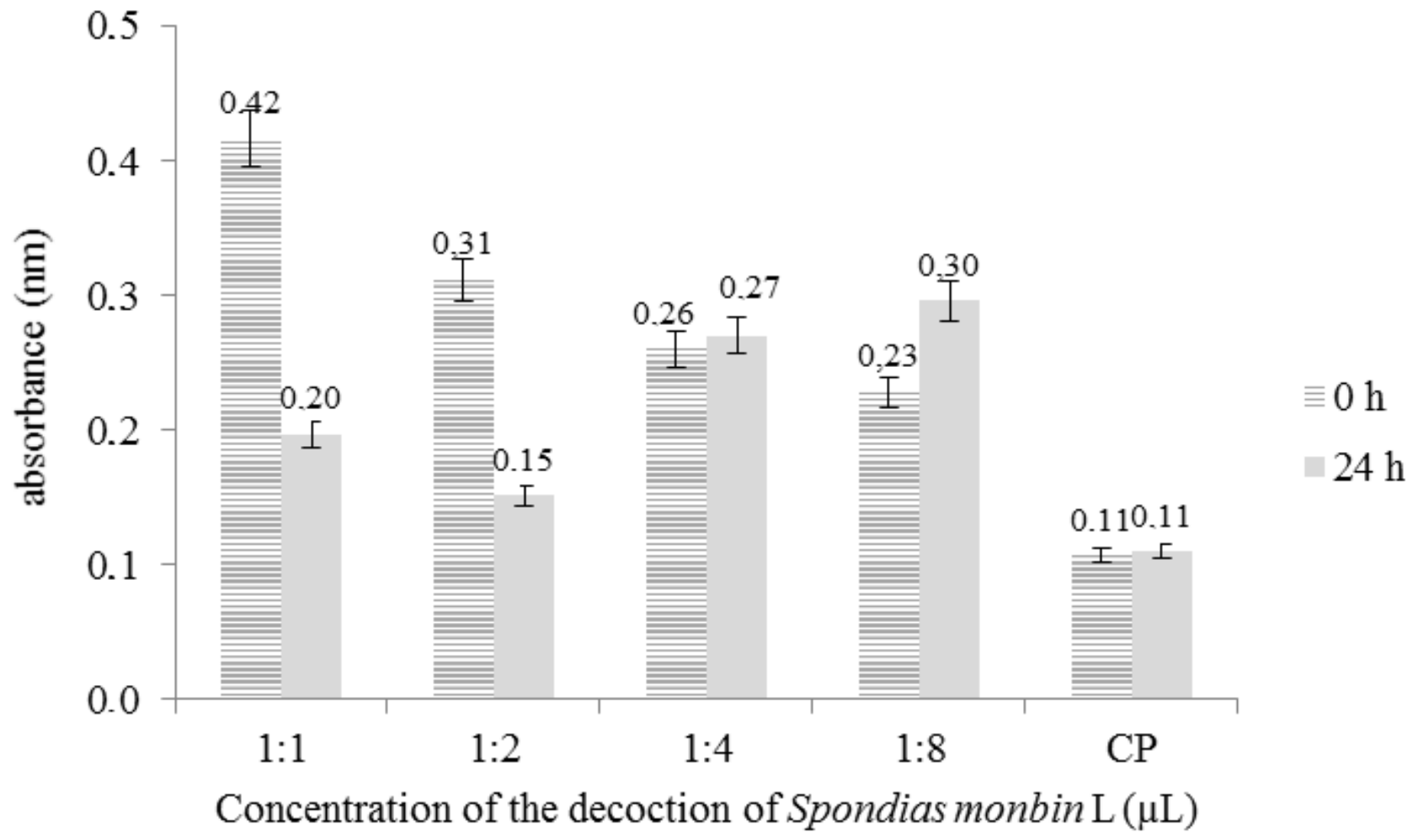

Figure 2. Absorbances according to the concentrations of the extracts of $S$. mombin and the time of culture of the bacteria 0 and $24 \mathrm{~h}$, using decoct maintained at the temperature of $8^{\circ} \mathrm{C}$ during 7 days.

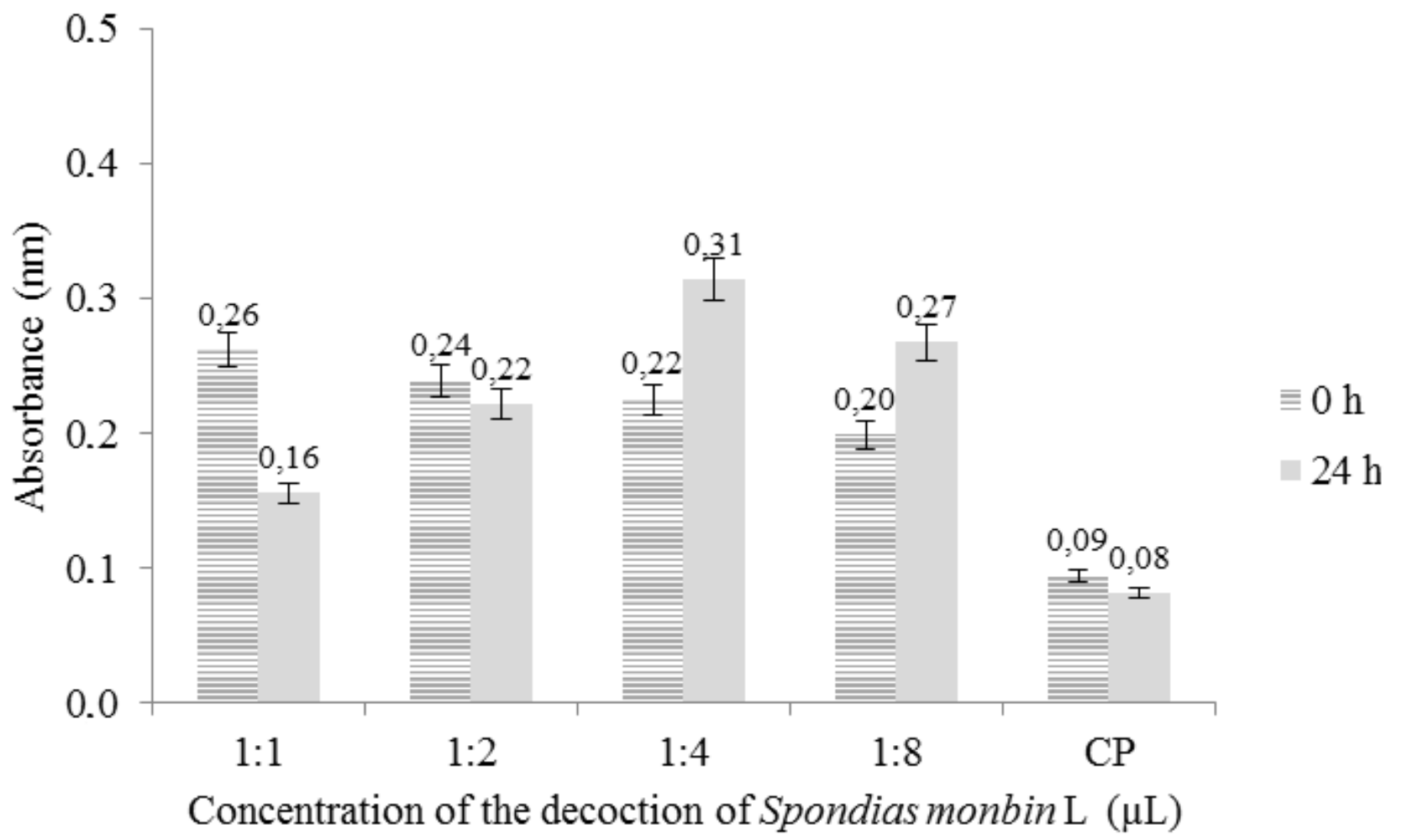

Figure 3. Absorbance as a function of the concentrations of the extracts of $S$. mombin and the time of culture of the bacteria during $24 \mathrm{~h}$ using decoct with 7 days maintained at $25^{\circ} \mathrm{C}$. 


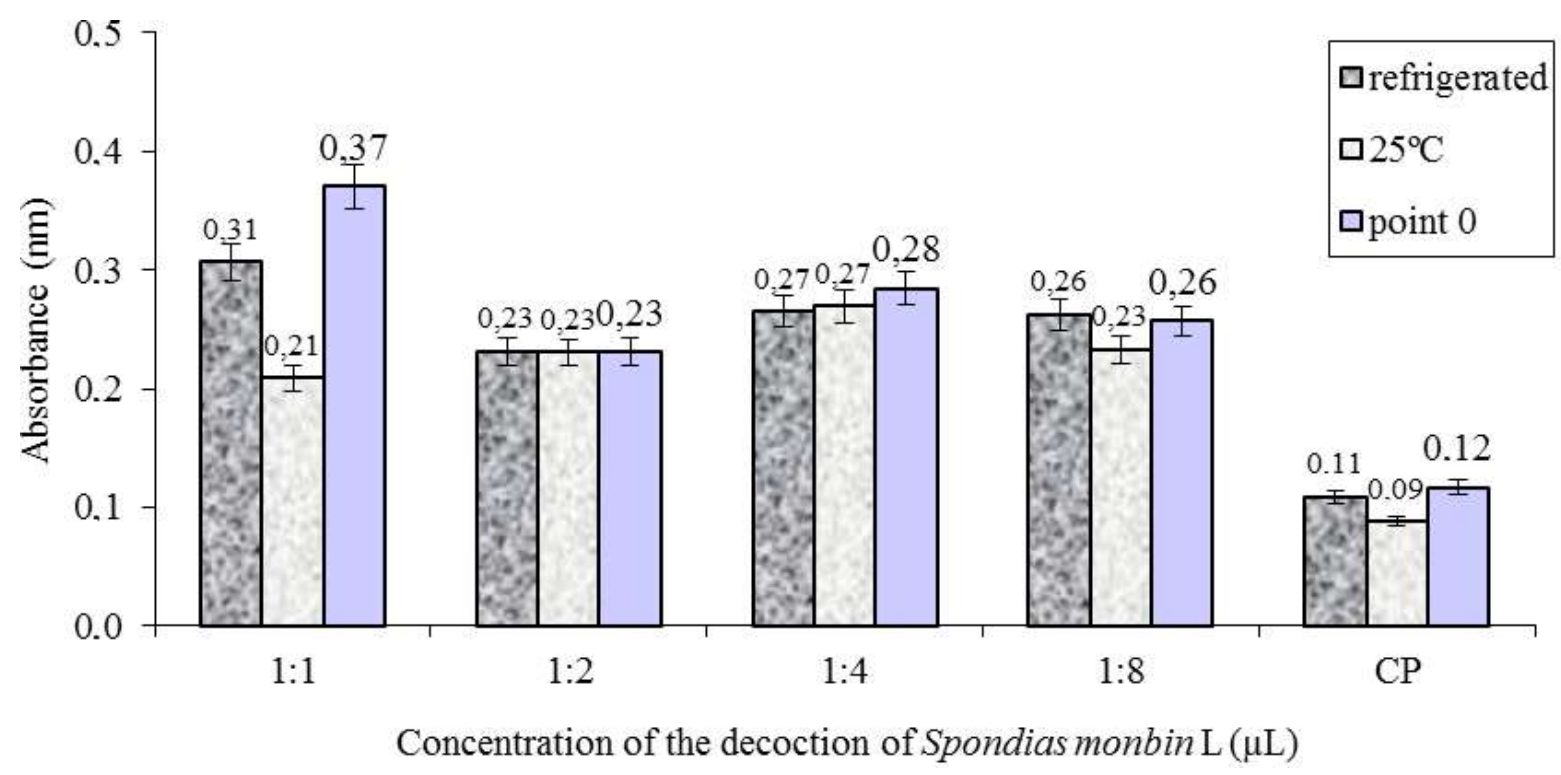

Figure 4. Mean values of the absorbance values in relation to the extract concentrations, at temperatures $0^{\circ}$ and $25^{\circ} \mathrm{C}$, compared with the means of the positive control.

\section{Eesistant Sensitive}

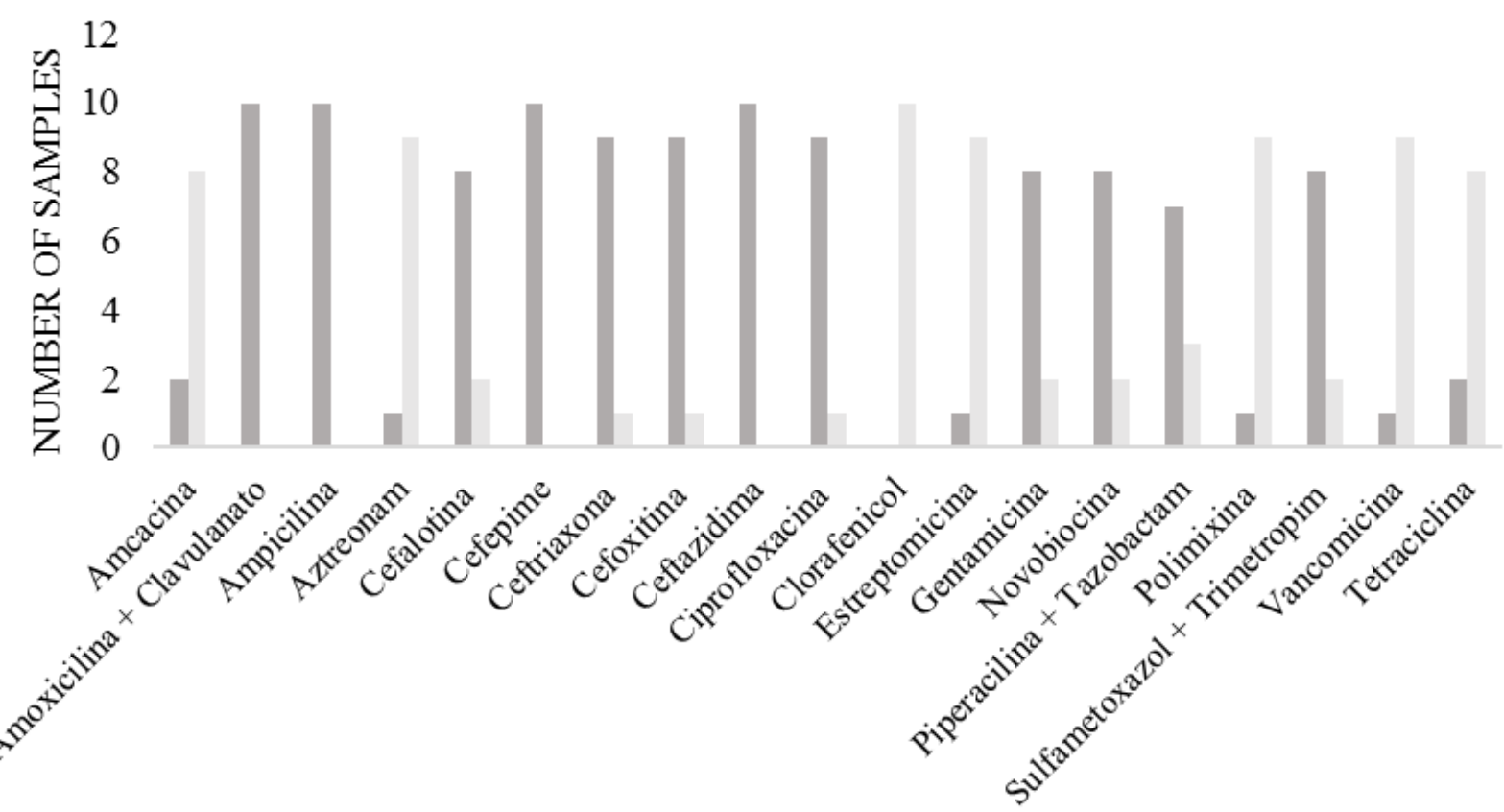

Figure 5. Demonstration of susceptibility and resistance of 10 bacterial strains against traditional antimicrobials.

obtained a positive response regarding the inhibition of the strains.

Comparing the average concentrations between all the extracts, the values of the extract at $25^{\circ} \mathrm{C}$ with a concentration of $1: 1$ performed better in relation to the refrigerated decoction, developing the lowest absorbance $(0.21 \mathrm{~nm})$. The extracts averages at concentrations of
1:2, 1:4 and 1:8 had no significant statistical changes during inhibition at different temperatures and on the different days they were analyzed (Figure 4).

In Figure 5, it can be observed that $100 \%$ of the strains were resistant to amoxicillin + clavulanate, ampicillin, cefepime and ceftazidime, being characterized with a multiresistant profile; that is, they are resistant to four or 
more antibiotics. Regarding the other strains, there was a variance between resistance and sensitivity against antibiotics and $100 \%$ showed sensitivity to chloramphenicol, which was therefore used as a positive control in the microplate analysis.

The results found in this research corroborate those found by Neves et al. (2010) and Cavalcante et al. (2013), who demonstrated that ampicillin is among the antimicrobials that show the highest resistance indices to Staphylococcus sp. However, the results of the present research are somewhat contradictory to those found by Langoni et al. (2006) and Moroni et al. (2005) concerning resistance of the isolates of Staphylococcus sp. to amoxicillin and who cited that the sensitivity to ampicillin varied.

According to Rice and Bonomo (2005), the mechanisms of resistance may be intrinsic to the microorganism or acquired by transmission of genetic material or mutation. In this study, it was observed that the resistance of the bacterial strains was against $\beta$ lactam antibiotics (amoxicillin + clavulanate, ampicillin, cefepime and ceftazidime). Concerning this, Fluit et al. (2001) believed that mutations in penicillin-binding proteins (PBPs) lead to a decrease in the binding affinity of the antibiotic to the site of action. $S$. aureus and Staphylococcus sp. of negative coagulase acquired the chromosomal gene, mecA, encoding PBP, which makes them resistant to $\beta$-lactams. The high resistance of this gene causes the inhibition of all $\beta$-lactams and maintains active cell wall synthesis, even in the presence of lethal concentrations of the antibiotic (Dzidic et al., 2008; Hawkey, 1998).

\section{Conclusions}

All strains were resistant to amoxicillin + clavulanate, ampicillin, cefepime and ceftazidime, being characterized with a multiresistant profile. This indicates that the extract of the leaf of cajá can be used as an alternative, since it was effective in the concentrations of 1:1 and 1:2 against all strains of coagulase negative Staphylococcus, regardless of storage temperatures.

\section{CONFLICT OF INTERESTS}

The authors have not declared any conflict of interests.

\section{REFERENCES}

Barroso GM, Morim MP, Peixoto AL, Ichasco CLF (1999). Frutos e Sementes: morfologia aplicada à sistemática de dicotiledôneas. Viçosa: Universidade Federal de Viçosa 433p.

Cavalcante MP, Alzamora Filho F, Almeida MGAR, Silva MS, Barros CGG, Silva MCA (2013). Bactérias envolvidas nas mastites subclínicas de cabra da região de Salvador, Bahia. Arqui. Inst. Biol. 80(1):19-26.
Diby SB, Koné M, Yapo A (2012). Potentiel pharmacologique des écorces de tige de Spondias mombin L. (Anacardiaceae) sur la motricité in vitro du duodénum de lapin; une plante médicinale utilisée dans le traitement traditionnel des troubles digestifs. Phytothérapie 10:306-312.

Duarte MCT (2006). Atividade antimicrobiana de plantas medicinais e aromáticas utilizadas no Brasil. Rev. Multiciênc. Campinas 7:1-16

Dzidic S, Suskovic J, Kos B (2008). Antibiotic resistance Mechanisms in Bacteria: Biochemical and Genetic Aspects. Food Technol. Biotechnol. 46(11):11-21.

Ferreira DF (2000). Sistema SISVAR para análises estatísticas: Manual de orientação. Lavras: UFLA/DCE. 37p.

Fluit A, Visser M, Schmitz F (2001). Molecular detection of Antimicrobial Resistance. Clin. Microbiol. Rev. 14(4):837-862.

Hawkey $P$ (1998). The origins and molecular basis of antibiotic resistance. Br. Med. J. 317:657-359.

Langoni H, Domingues PF, Baldini S (2006). Mastite caprina: seus agentes e sensibilidade frente a antimicrobianos. Rev. Bras. Ciênc. Vet. 13(1):51-54.

Medeiros AJD (2013). Aspectos tecnológicos e sociais do potencial antimicrobiano de plantas do semiárido sobre cepas bacterianas isoladas de caprinos. Dissertação de Mestrado, Universidade Federal Rural do Semi-Árido, Mossoró, Rio Grande do Norte P 79.

Moroni P, Pisoni G, Antonini M, Ruffo G, Carli S, Varisco G, Boettcher P (2005). Subclinical mastitis and antimicrobial susceptibility of Staphylococcus caprae and Staphylococcus epidermidis isolated from two Italian goat herds. J. Dairy Sci. Champaign 88(5):16941704.

Neves PB, Medeiros ES, Sá VV (2010). Perfil microbiológico, celular e fatores de risco associados à mastite subclínica em cabras no semiárido da Paraíba. Pesqui. Vet. Bras. Seropédica 30(5):379-384.

Rice L, Bonomo R (2005). Genetic and Biochemical mechanisms of bacterial. In Viclor Lorian, M. D. (Eds). Antibiot. Lab. Med. 5:441-476.

Sacramento CK, Souza FX (2000). Cajá (Spondias mombin L.). Jaboticabal: Funep 42p. (Funep.Série Frutas Nativas, 4). 